\title{
CORRIGENDUM
}

\section{KIR-ligand incompatibility in the graft-versus-host direction improves outcomes after umbilical cord blood transplantation for acute leukemia}

R Willemze, CA Rodrigues, M Labopin, G Sanz, G Michel, G Socié, B Rio, A Sirvent, M Renaud, L Madero, M Mohty, C Ferra, F Garnier, P Loiseau, J Garcia, L Lecchi, G Kögler, Y Beguin, C Navarrete, T Devos, I lonescu, K Boudjedir, A-L Herr, E Gluckman and $\mathrm{V}$ Rocha on behalf of Eurocord-Netcord and Acute Leukaemia Working Party of the EBMT, Paris (F)

Leukemia (2009) 23, 630; doi:10.1038/leu.2009.11

Correction to: Leukemia (2009) 23, 492-500; doi:10.1038/ leu.2008.365; published online 8 January 2009

Since the publication of this paper, the authors have noted that the affiliation for author ' $L$ Lecchi' is incorrect.
The correct affiliation is Milano Cord Blood Bank, Fondazione Ospedale Maggiore Policlinico, Mangiagalli e Regina Elena, Italy.

The Authors would like to apologize for this error. 